\title{
MEMBANGUN GENERASI EMAS DENGAN VARIASI PEMBELAJARAN ONLINE DI MASA PANDEMI COVID-19
}

\author{
Erna Pujiasih \\ SMA Negeri 1 Bantul \\ erpujiasih@gmail.com
}

\begin{abstract}
Abstrak: Pendidikan merupakan dasar dari kemajuan pembangunan bangsa. Siswa sebagai generasi emas dipersiapkan untuk masa depan. Guru merupakan kunci utama keberhasilan untuk menghasilkan generasi emas Indonesia tahun 2045 yang bermutu dan berkualitas. Negara menghadapi wabah yang sedang terjadi yaitu pandemi COVID-19. Karena situasi demikian maka pemerintah menerapkan pembelajaran secara online dimana siswa belajar di rumah untuk menghindari terpaparnya COVID-19. Tujuan tulisan ini untuk memberikan inspirasi guru dalam menerapkan model pembelajaran online agar siswa tetap mendapatkan pendidikan yang berkualitas. Untuk mengaplikasikannya maka diperlukan pembelajaran yang bervariasi agar siswa bersemangat dalam belajar. Pembelajaran online tersebut dapat dilakukan dengan cara virtual, berkelompok untuk berdiskusi, pemberian materi dalam bentuk video, rekaman, powerpoint, modul, lembar belajar, permainan dengan game quizizz dan penilaian secara online. Berdasarkan data kuesioner 322 siswa diperoleh kelebihan dan kekurangan pembelajaran online ini dimana siswa yang senang belajar online di rumah $45 \%$ dan siswa yang tidak senang $55 \%$. Kelebihan pembelajaran ini siswa lebih efektif dalam belajar, tidak lelah, menyenangkan, pengalaman baru dan kelemahannya adalah koneksi internet yang kurang baik, siswa kurang paham dengan materi, siswa merasa lelah, siswa tidak bisa berdiskusi dengan teman. Berdasar dari masalah tersebut maka pembelajaran online yang menarik dan bervariasi akan memberikan manfaat bagi generasi emas dalam belajar.
\end{abstract}

Kata kunci: pembelajaran, online, variasi kegiatan, generasi emas, COVID-19

\section{BUILDING A GOLDEN GENERATION BY APPLYING VARIOUS ONLINE LEARNING IN THE PANDEMIC OF COVID-19}

\begin{abstract}
Education is the basic requirement to develop a country. Students as the golden generation were prepared for the future. Teachers is the main key for education to produce high quality golden generation in 2045. Our country was facing the pandemic of COVID 19. The government applied online learning method where students had to study at home to prevent them from COVID 19 infection. The aim of this study is to give inspiration for teachers in teaching activities so that the students got noble quality education. To apply online learning, teachers needed various learning techniques to make students well-motivated. Online learning could be done by using virtual teaching, group discussion, video, recording, power point, module, worksheet, quiz, game, and online assessment. The data from questionnaire showed the strength and weaknesses of online learning where $45 \%$ of students liked and $55 \%$ of them disliked. The strength of online learning was the students could learn effectively, got fun and got new experiences. The weakness was some students got bad internet connection, could not understand the material, felt tired, and could not discuss with friends. The problem above showed that interesting and various online learning methods would give benefits for golden generation in learning. Keywords: learning, online, various activity, golden generation, COVID-19
\end{abstract}

\section{PENDAHULUAN}

Pendidikan merupakan dasar yang paling penting untuk menghadapi era society 5.0 yang menjadi tantangan berat apabila sumber daya manuasia tidak dipersiapkan dengan baik dan matang untuk generasi emas sebagai penerus kemajuan bangsa. Pembelajaran yang dilakukan guru dan siswa sebagai bekal siswa untuk mendapatkan bekal yang terbaik untuk mendapatkan pendidikan dan pembelajaran yang bermakna.
Guru sebagai kunci utama keberhasilan untuk menghasilkan generasi emas Indonesia tahun 2045 yang bermutu dan berkualitas. Oleh karena itu guru harus mempunyai kemampuan dalam mendesain pembelajaran agar bermakna dan bermanfaat

Negara kita saat ini sedang menghadapi pandemi virus corona sehingga siswa di minta untuk belajar di rumah untu menghindari terpaparnya COVID -19. Guru dan siswa harus melakukan pembelajaran secara online atau 
tidak tatap muka di kelas sepertii biasanya. Kejadian seperti ini menuntut siswa dan guru harus belajar dan melakukan pembelajaran secara online atau jarak jauh. Pembelajaran tetap harus berlangsung meski disaat terjadi pendemi COVID-19 agar generasi emas tidak ketinggalan dalam belajar dan tetap melakukan pembelajaran demi kemajuan generasi penerus sebagai ujung tombak kemajuan bangsa di masa yang akan datang.

Oleh karena itu guru harus membekali siswa mereka dengan dengan pendidikan dan keterampilan yang tidak hanya meliputi keterampilan bertahan hidup tapi juga keterampilan berpikir kritis, konstruktif, inovatif dan berkarakter.

Pada saat pembelajaran online maka komunikasi jarak jauh tidak lepas dengan penggunaan telepon genggam, tablet, atau laptop berikut koneksi internet yang dapat dimanfaatkan sebagai bagian dari kegiatan pembelajaran. Pencarian bahan ajar sebagai materi diskusi atau pemanfaatan berbagai video pembelajaran yang tersedia gratis di berbagai situs-situs pendidikan untuk menujang pembelajaran ini sangat dibutuhkan pada saat seperti ini.

Tujuan tulisan ini untuk memberikan inspirasi guru dalam menerapkan model pembelajaran online agar siswa tetap mendapatkan pendidikan yang berkualitas. Untuk mengaplikasikannya maka diperlukan pembelajaran yang bervariasi agar siswa semangat belajar dan tidak bosan. Proses belajar dan mengajar yang menarik dan menyenangkan membutuhkan kegiatan yang kreatif, inovatif dan menyenangkan agar siswa mampu berpikir kritis, kreatif dan konstruktif. Bagaimana model pembelajaran secara online yang dapat dilakukan pada saat pandemi COVID -19 yang sesuai untuk belajar bagi siswa? Bagaimana variasi kegiatan yang dilakukan dalam pembelajaran secara online? Bagaimana langkah pembelajaran online? Apakah kelebihan dan kekurangan dengan pembelajaran secara online?

\section{Kreatifitas dan Variasi Pembelajaran yang Menyenangkan}

Pada bagian ini mendiskusikan tentang pembelajaran yang kreatif dan bervariasi yang terdiri dari model pembelajaran online, variasi kegiatan pembelajaran dan kelebihan kegiatan pembelajaran tersebut.
Model pembelajaran dalm konteks ini merupakan landasan praktik pembelajaran hasil penurunan teori psikologi pendidikan danteori belajar yang dirancang berdasarkan proses analisis yang diarahkan pada implementasi kurikulum dan implikasinya pada tingkat operasional didepan kelas menurut Agus Wasisto Dwi (2020:67) Maka untuk mewujudkan variasi pembelajaran dibutuhkan krativitas model pembelajaran yang bervariasi.

Menurut Mega Wulandari dan Truly Almenda (2020: 142-144) Pembelajaran yang dikombinasi atau bervariasi (Blended learning) dapat mengembangkan dan memperluas proses pembelajaran dengan membeikan variasi pembelajaran tentang lingkungan dan materi pembelajarannya. Pembelajaran yang dikombinasi ini tidak hanya satu macam kegiatan namun bisa di lakukan dengan online, offline, mendengarkan audio, video, membaca materi sendiri untuk menambah kemampuan peningkatan diri, berkolaborasi, berkomunikasi dengan berbagai aplikasi seperti Skype, eForum, messengers, email menurut pilihannya masing-masing siswa.

Untuk mewujudkan pembelajaran yang bervariasi dan menyenangkan secara online ada beberapa kegiatan yaitu:

\section{Pembelajaran dengan ceramah/ virtual secara online}

Paradigma belajar secara online telah mengubah pengajaran berorientasi berpusat pada guru namun lebih mementingkan untuk lebih berorientasi ada siswa. Pembelajaran Di era digital ini pembelajaran yang efektif dengan menggunakan teknologi. Apalagi saat pademi COVID 19 yang sedang dialami saat ini. Maka pembelelajaran secara online ini harus dilakukan oleh guru dan siswa sehingga siswa tetap belajar.

Untuk melakukan pembelajaran yang bervariasi diantaranya dengan ceramah. Metode ceramah memberikan penerangan secara lisan kkepada siswa kemudian siswa mencatat seperlunya. Kegiatan ini bisa dilakukan dengan penjelasan secara singkat dan padat sehingga tidak membutuhkan waktu yang lama untuk ceramah.

Untuk membantu penjelasan guru dapat menyajikan bahan ajar yang disampaikan secara sistematis menggunakan media yang dapat menarik perhatian siswa. Penyampaiannya juga tidak terlalu lama agar 
konsentrasi siswa untuk mendengarkan penjelasan menjadi bermakna. Pembelajaran ini bisa dilakukan secara online dengan menggunakan aplikasi zoom, jitzi, google class meet, webex, membuat video penjelasan singkat yang bisa dibagikan dengan WhatsApp, youtube dan rekaman video yang media ini bisa digunakan secara berulang-ulang. Dalam hal ini guru dituntut bisa menggunakan teknologi untuk digunakan dalam pembelajaran dan memerlukan fasilitas handphone atau gadget yang mendukung pembelajaran secara online dan bisa menggunakannya serta dapat terhubung internet.

Pembelajaran virtual ini dilakukan dengan tatap muka melalui gadget (handphone atau laptop) namun menggunakan aplikasi online. Siswa memerlukan penjelasan yang dilakukan secara langsung, hal ini untuk memfasilitasi siswa yang gaya belajarnya secara auditiory (mendengarkan) dan secara visual atau melihat langsung. Karena kadang-kadang siswa mendapatkan kesulitan pemahaman jika hanya membaca materi tanpa penjelasan langsung dari guru. Guru bisa menjelaskan inti dari pelajaran yang akan diberikan sesuai dengan tujuan belajar yang akan dilakukan

Metode ceramah secara online ini dapat membuat pembelajaran lebih jelas dan konkrit, sehingga diharapkan dapat dipahami secara mendalam dan bertahan lama dalam pikiran siswa.

\section{Pembelajaran dengan menggunakan Google Classroom}

Pembelajaran dengan E-Learning secara online ini membutuhkan sistem menejeman dalam pembelajaran untuk mempermudah guru dan siswa dalam memasuki kelas sebagai tempat pengganti diruang kelas.

Fasilitas yang tersedia dari internet dengan menejeman pembelajaran E-Learning yang bisa di gunakan yaitu Google Classroom. Dengan aplikasi ini guru bisa memberikan materi lewat fasilitas untuk berbagi video, rekaman, materi, PowerPoint, modul belajar, lembar kegiatan belajar dan sumber belajar yang bisa diperoleh dari internet

Siswa juga bisa menggunduh atau mendownload materinya. Siswa juga dapat dikelompokkan dalam kelas -kelas sehingga guru dapat memanajemen kelas dengan baik seperti halnya di ruang kelas sekolah namun dalam bentuk kelas secara online. Di masa pandemi COVID-19 aplikasi ini sangat efektif untuk digunakan dan memudahkan guru dalam memberikan pembelajaran jarak jauh untuk tetap memberikan pendidikan generasi emas.

Guru bisa melakukan diskusi di kelas dengan fasilitas melalui komentar siswa dan guru secara online walaupun secara tertulis. Siswa dan guru dapat saling berdiskusi dengan materi yang sedang dipelajari wlaupun tidak tatap muka namun media ini sudah bisa digunakan untuk tetap berlangsungnya pembelajaran di kelas. Pengumuman apa yang akan dilakukan dalam pembelajaran dapat juga dilakukan dengan aplikasi ini, karena siswa langsung dapat mengakses melalui hp dan pesan ini sudah masuk secara langsung di gmail yang digunakan siswa dalam pembelajaran online.

Google classroom ini siswa juga bisa mengerjakan kuis atau tes yang bisa diketahui nilainya secara langsung. Siswa juga bisa mendapatkan nilai tugas yang sudah dikerjakan melalui media ini. Sehingga pembelajaran ini bisa dilakukan secara efektif dan efisien.

\section{Pembelajaran Kooperatif}

Pembelajaran yang berpusat pada siswa sangat efektif untuk mengembangkan siswa dalam ketrampilan berpikir dan mampu menyelesaikan masalah seperti yang diharapkan untuk menghadapi era 5.0 dimana siswa menjadi sumber daya manusia yang dipersiapkan dengan baik dan matang untuk generasi emas sebagai penerus kemajuan bangsa.

(https://mediaindonesia.com/read/detail/25927 0 -seluruh-pegiat-pendidikan-diminta-bersiaphadapi-era-society-5.0)

Oleh karena itu guru harus mengubah cara mengajar dan menyampaikan materi sehingga ada kesempatan yang luas untuk belajar bersama dan saling diskusi atau berbagi informasi. Kelompok kerja memberikan siswa untuk menghasilkan sesuatu dan mengembangkan siswa saling berkolaborasi.

Model Pembelajaran ini juga menggunakan kegiatan kelompok sehingga guru menggunakan pembelajaran kooperatif menurut Miftakhul Huda (2013: 110-114) berdasar teori dari Robert Slavin dan Shlomo Sgaran menyatakan bahwa pengembangan pembelajaran kooperatif bahwa sinergi yang akan muncul melalui kerjasama akan meningkatkan motivasi yang jauh lebih besar dari pada melalui lingkungan individual. 
Untuk melakukan pembelajaran kooperatif secara online bisa dilakukan dengan membagi kelompok kemudian siswa berkelompok untuk mendiskusikan tugasnya secara kelompok dengan menggunakan WhatsApp grup. Siswa bisa saling diskusi antara 5-8 siswa dengan menggunakan aplikasi ini. Jadi walaupun jarak jauh namun siswa bisa saling komunikasi secara virtual dengan WhatsApp grup ini.

Selain itu siswa juga bisa saling berdiskusi dan berpendapat dengan fasilitas komentar yang ada di Google Classroom. Peran guru sangat penting agar memotivasi siswa untuk aktif dan bisa menyampaikan pendapatnya meski secara tertulis. Guru bisa memberikan permasalahan, video, materi kemudian siswa memberikan pendapat atau komentarnya.

\section{Pembelajaran dengan game quizizz}

Untuk memberikan kegiatan pembelajaran yang bervariasi guru juga bisa menyertakan dengan game karena game ini akan membuat siswa lebih senang sehingga tidak monoton atau bosan. Menurut Hoby 1995 hal 486 mendefinisikan game adalah kegiatan yang digunakan untuk memperoleh kesenangan. Oleh karena itu game dapat didefinisikan suatu alat yang digunakan untuk menarik motivasi siswa untuk menyertai proses belajar dan mengajar karena game dapat membuat siswa lebih fokus dalam belajar, siswa tidak merasa bahwa mereka sedang belajar.

Game juga membuat siswa untuk menggunakan pengalaman baru dengan bahasa asing yang tidak seperti belajar materi yang dipelajari. Game merupakan metode yang akan memberikan banyak manfaat untuk guru dan siswa yang lain. Buckby (1994 hal 82) mengatakan manfaat game yaitu untuk menarik siswa untuk belajar bahasa Inggris karena dengan game ini menyenangkan dan membuat mereka untuk bereksperimen, menemukan dan berintraksi dengan lingkungannya.

Game yang bisa digunakan untuk siswa dalam memberikan kuis adalah quizizz. Menurut Mega Wulandari dan Truly Almenda (2020: 80) Quizizz adalah aplikasi digital yang dapat digunakan untuk mengetahui ketercapaian dan evaluasi kemampuan siswa memahami materi.

Game quizizz ini dapat dilakukan secara online namun siswa akan senang untuk mempelajari materi yang dipelajari. Guru bisa membuatkan grup atau kelompok untuk bermain dan bisa juga dilakukan secara individu. Siswa dapat langsung mengetahui skor yang diperoleh dan kesalahan yang dilakukan dalam mengerjakan latihan di game tersebut. Yang dilakuka guru untuk melakukan game quizizz ini guru memilih materi yang diperlukan yang sudah di ada diinternet atau bisa membuat sendiri materi kuis yang akan diberikan untuk siswa.

Untuk memainkan game ini guru memberikan kode yang akan dimainkan, setelah siswa hadir sebagai pemain game guru bisa memulai game sambil memantau jalannya permainan game quizizz ini, setelah selesai game guru bisa memberikan hasil skor siswa yang sudah dilakukan. Kegiatan ini sangat menyenangkan karena siswa tidak merasa bahwa mereka sedang belajar. Pembelajaran dengan quizizz ini menyenangkan karena siswa dapat berlatih dan menilai kemampuannya setelah mempelajari suatu materi.

\section{Pembelajaran dengan menghasilkan karya / produk dan bermakna}

Pembelajaran dalam online ini tidak hanya memberikan materi pelajaran namun guru juga harus menyiapkan generasi emas yang berkualitas. Menurut Regina Ade Darman (2017) bahwa guru harus membekali siswa mereka dengan dengan pendidikan dan keterampilan yang tidak hanya meliputi keterampilan bertahan hidup tapi juga keterampilan berpikir kritis, konstruktif, inovatif dan berkarakter.

Oleh karena itu guru dituntut untuk mendesain atau merencanakan pembelajaran yang berkualitas dan bermakna agar siswa dapat menghubungkan pembelajaran dengan kehidupan sehari-hari dan permasalahan yang sedang dihadapi pada saat ini. Misalnya guru memberikan materi yang berhubungan dengan COVID-19, bencana alam, pemanfaatan sumber daya alam, kepedulian terhadap lingkungan dan memberikan pembelajaran yang membuat siswa berkarakter. Walaupun dalam pembelajaran on line ini siswa dan guru tidak bertemu langsung namun guru juga mengajak siswa untuk disiplin, kerjasama, saling menghargai, punya sopan santun, jujur dan saling peduli dengan yang lainnya.

Pembelajaran dapat juga dengan cara memberikan penugasan (e-portofolio) pada siswa dengan variasi kegiatan misalnya dengan membuat sesuatu yang dapat dihasilkan secara visual berupa karya misalnya video, rekaman, 
poster, gambar dan peta konsep materi yang dipelajari. Karya ini dapat di foto kemudian dikumpulkan melalui google classroom.

Siswa mendapatkan komentar atau nilai dari guru dengan karya yang dibuat disamping itu siswa juga sudah belajar dengan materi yang dipelajarinya. Aplikasi untuk pembuatan karya bisa menggunakan fasilitas yang ada di internet sehingga siswa semakin keatif untuk belajar dan menghasilkan suatu karya.

Untuk memberikan pembelajaran yang bermakna guru harus mendesain materi yang kontekstual sesuai dengan masalah dalam kehidupan sehari-hari dan materi yang memberikan manfaat dan membimbing siswa untuk menjadi generasi emas yang berkarakter dalam mempersiapkan masa depannya.

\section{Penilaian secara online}

Penilaian merupakan satu hal yang penting bagi guru untuk mengukur sampai seberapa siswa dapat mencapai dari tujuan pembelajarannya. Untuk melakukan penilaian guru bisa menggunakan google form yang bisa langsung dibuat di dalam Google Classroom. Media ini efektif untuk digunakan dalam penilaian karena hasilnya sudah terekap dalam aplikasi ini. Guru juga bisa langsung mengetahui hasilnya sehingga mempermudah guru dalam mengoreksi.

Penilaiannya ini juga bisa bervariasi dari pilihan ganda, uraian, menjodohkan dan menulis karangan dapat dilakukan di google form ini. Data yang tersimpan ini tidak akan hilang karena semua sudah tersimpan di satu tempat di Google Classroom ini.

\section{MODEL PEMBELAJARAN ONLINE}

Pembelajaran online merupakan pembelajaran yang dilakukan secara online melalui jaringan atau koneksi internet. Menurut Nur Hadi (2006) model pembelajaran online dapat digunakan untuk menyampaikan pembelajaran tanpa dibatasi ruang dan waktu, dapat menggunakan berbagai sumber yang sudah tersedia di internet, bahan ajar relatif mudah diperbaharui dan selain itu untuk lebih meningkatkan kemandirian siswa dalam melakukan proses pembelajaran.

Untuk memberikan pembelajran online guru dituntut mampu menggunakan teknologi internet yang bisa mempermudah guru dalam memberikan pembelajaran. Guru harus mempunyai kemampuan dan ketrampilan dalam menggunakan media-media dari laptop dan aplikasi yang digunakannya.
Berikut ini langkah-langkah yang bisa dilakukan saat model pembelajaran secara online untuk tetap membangun generasi emas yang bisa dilakukan oleh guru.

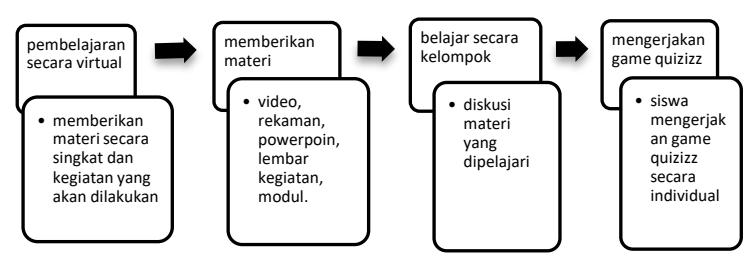

Gambar 1. Langkah-langkah pembelajaran online yang bervariatif

Berdasarkan gambar diatas, pembelajaran dapat dilakukan secara bervariasi dalam satu pertemuan yang bisa dimulai langkah pertama dengan pembelajaran secara virtual dengan aplikasi misalnya zoom, webinar, webex, google class meet atau rekaman, video yang sudah disiapkan sebelumnya.

Langkah selanjutnya dengan memberikan materi yang bisa di bagikan dengan aplikasi google classroom, dimana siswa dapat membuka materi kapanpun dan menyimpannya di sini. Materi yang bisa dibagikan kepada siswa bervarisai sehingga siswa tidak jenuh dengan hanya satu materi yang monoton seperti video, rekaman, powerpoint, lembar kegiatan siswa, modul, sumber dari internet dalam bentuk alamat web, you tube dan sebagainya

Langkah berikutnya siswa dapat melakukan diskusi / tugas secara berkelompok, siswa bisa berdiskusi dengan WhatsApp group secara berkelompok dan hasilnya bisa dibagikan lewat komentar pada google classroom.

Selanjutnya kegiatan individu dapat dilakukan dengan melakukan game quizizz sehingga siswa dapat memahami materi ini sambil bermain namun mereka juga memahami materi yang sedang dipelajari.

Pembelajaran online dengan bervariasi ini akan membuat siswa senang belajar dan tidak merasa jenuh atau bosan. Siswa juga mendapat pembelajaran dengan mendapat pemahaman lagsung dari guru, siswa juga bisa memdaptkan materi secara lengkap, siswa dapat berdiskusi secara berkelompok dan terakhir siswa dapat mengerjakan latihan secara individual.

Mega Wulandari dan Truly Almenda (2020: 99) berpendapat bahwa teknologi menjadi peralatan yang bagus dan kuat dalam mengajar terutama dalam; Membantu guru dalam mendesain dan mengembangkan rencana pembelajaraan kapan dan dimanapun berada; Membuat guru kontak dekat dengan 
siswa; Menyediakan siswa materi sebelum dan setelah pembelajaran di kelas; Memberikan pengembangan siswa secara mandiri berkolaborasi dan memonitor proyeknya untuk mencapai tujuan secara umum.

Berdasarkan pendapat tersebut bahwa pembelajaran dengan online dan teknologi yang digunakan dapat membantu guru dan siswa menggunakan waktu dan energy dengan pembelajaran yang efektif. Pembelajaran online ini siswa dituntut untuk mandiri dan kreatifitas dalam belajar sehingga kemampuan siswa untuk memanfaaatkan media belajar dari internet dan materi yang diberikan oleh guru.

\section{KELEBIHAN DAN KELEMAHAN PEMBELAJARAN ONLINE}

Pembelajaran online mempunyai kelebihan maupun kekurangan. Untuk mendukung dan mengetahui sejauh mana siswa merespon pembelajaran online ini guru meminta siswa untuk memberikan komentar dan pendapatnya tentang pembelajaran online yang dilakukannya. Dari data yang diperoleh kuesioner dari siswa yaitu:

Berdasarkan data kuesioner 322 siswa didapatkan siswa yang yang senang dengan pembelajaran online ini sejumlah $45 \%$ dan data siswa yang tidak senang dengan pembelajran online ada $55 \%$

Berdasarkan hasil yang didapatkan dari jawaban dan pendapat siswa terhadap kegiatan pembelajaran online baik yang senang atau tidak senang atau kekurangan dan kelebihan pembelajaran tersebut

Berdasarkan data kuesioner kelebihan pembelajaran online diperoleh sebagai berikut:

a. Menyenangkan dan menarik

b. Efektif dan lebih mengerti materi yang dipelajari

c. Bagus/ baik

d. belajar sambil bermain

e. belajar hal yang baru dengan online

f. siswa tidak lelah dan bisa santai dalam belajar

g. Siswa mendapat semangat dalam belajar

Berdasarkan data kuesioner kelemahan pembelajaran online tersebut diperoleh sebagai berikut:

a. siswa bosan belajar dirumah dan senang belajar di sekolah

b. kesulitan dalam koneksi internet dan menghabiskan banyak kuota

c. siswa tidak bisa berdiskusi dan bertemu secara langsung d. siswa lebih mengerti dengan penjelasan dari guru secara langsung

e. siswa kesulitan memahami materi yang diajarkan jika tanpa penjelasan guru secara langsung.

f. siswa merasa banyak beban tugas yang diberikan oleh guru

g. siswa merasa stress dengan tugas melalui online

h. siswa pusing dan lelah berada di depan laptop atau handphone secara terus menerus

Berdasarkan pengamatan dan pelaksanaan pembelajaran secara online yang dilakukan selama pembelajaran pandemi COVID-19, siswa bisa mengikuti pembelajaran secara online dengan baik. Hampir 90\% siswa mengikuti apa yang diberikan ajarkan guru, siswa mengikuti secara online dengan cara mengikuti virtual secara langsung dengan mendengar penjelasan guru melalui zoom, Google Class meet ataupun video, kemudian membuka materi yang ada di Google Classroom untuk belajar materi secara mandiri baik itu berupa video, rekaman, bacaan dan PowePoint yang diberikan guru.

Untuk berdiskusi siswa juga mau berpendapat melalui komentar yang ada di Google Classsroom. Setelah siswa belajar mandiri siswa bisa menanyakan jika mendapat kesulitan melalui langsung bertanya pada guru atau minta penjelasan. Siswa juga mengerjakan tugas yang ada di didalam Google Classroom dan menggumpulkan lewat Google Form atau sesuai dengan yang disediakan oleh guru.

Untuk mengecek keaktifan siswa guru memberikan kuis untuk siswa agar siswa tidak jenuh dalam belajar. Siswa bisa diajak bermain game quizizz. Kegiatan ini membuat siswa tertarik sehingga terkadang siswa minta untuk bermain lagi. Kegiatan kuis ini juga membantu siswa memahami materi yang sudah dipelajari.

Pembelajaran online kadang berjalan tidak semestinya, karena beberapa kendala. Masalah yang biasanya didapatkan dari siswa adalah siswa tidak disiplin saat jam pelajaran, siswa belum siap pelajaran, koneksi internet tidak lancar, listrik mati dan kehabisan kuota internet. Pembelajaran online ini siswa juga merasa jenuh karena hanya berhadapan dengan komputer atau hanphone saja.

Siswa mengerjakan latihan dengan terlambat yang diberikan oleh guru dan terkadang guru memberikan tugas tidak melmperhatikan waktu yang sesuai dengan jam 
pelajarannya. Hal tersebut membuat siswa juga merasa terbebani dengan banyaknya tugas yang diberikan oleh guru, masalh tersebut muncul karena siswa maupun guru tidak membatasi waktu pelajaran seperti yang dilakukan di kelas, dimana siswa sudah diatur jadwal belajar dan istirahatnya. Namun jika pembelajaran yang dilakukansecara online dan tidak tatap muka ini menjadikan siswa dan guru tidak terbatasi ruang dan waktu.

Peran guru disini juga sangat penting karena guru selain memberikan materi pembelajaran guru juga harus memotiasi siswa dan mengetahu kondisi siswa saat ini diaman siswa harus belajar di rumah dan tidak bisa bertatap muka langsung untuk belajar. Guru harus mengatahui psikologis siswa dan keadaan saat pandemi COVID-19 ini yang mana guru harus meningkatkan kemampuan guru untuklebih banyak belajar dalam menggunakan alat teknologi untuk menunjang pembelajaran secara online.

Untuk mengaplikasikan pembelajaran online ini banyak ditemui kesulitan dalam keterbatasan pengetahuan untuk menggunakan teknologi dalam pembelajaran online. Kesulitan guru memanfaatkan teknologi yang belum pernah dipelajari sebelumnya dan guru harus menggunaknnya untuk pembelajaran, selain itu siswa juga penyesuaian belajar dengan cara online yang sebelumnya jarang dilakukan dan hanya bergaantung pada pembelajaran tatap muka secara langsung. Pembelajaran online ini memerlukan kerjasama yang baik antara guru, siswa, orangtua dan sekolah untuk dapat berjalan dengan baik dan lancar. Sehingga generasi emas akan selalu belajar untuk mejadi siswa yang berkualitas yang mempunyai karakter yang baik, beripikir kritis, kreatif, produktif, mandiri, dan dapat mengembangkan potensi diri secara maksimal.

\section{KESIMPULAN}

Mengajar dengan pembelajaran online untuk membangun dan mempersipkan generasi emas tahun 2045 diperlukan varisai kegiatan pembelajaran karena pembelajaran ini dilakukan secara monoton yang siswa dan guru hanya berada di depan laptop maupun handphone. Generasi emas harus tetap mendapatkan pembelajaran di masa pandemi COVID 19 dan guru tetap memberikan pembelajaran yang berkualitas agar siswa tidak ketinggalan dalam belajar serta membekali siswa berpikir kritis, kreatif, produktif dan bisa mengembangkan potensinya meski dalam sistuasi darurat.

Pembelajaran dengan kegiatan variatif meliputi pembelajaran virtual dengan ceramah, pembelajaran online melalui google classroom, pembelajaran kooperatif untuk berdiskusi, pembelajaran dengan bermain game quizizz, pembelajaran yang bisa membuat hasil karya dan bermakna serta penilaian secara online.

Pembelajaran online ini terdapat kelebihan dan kelemahannnya oleh karena itu guru dan siswa harus memahamai kondisi saat ini demi berlangsungnya pembelajaran untuk menyiapkan generasi emas mendatang dalam menghadapi era society 5.0 yang menuntut untuk berpikir kritis, kreatif dan produktif. Pembelajaran online ini satu-satunya cara yang bisa digunakan pada masa pandemi COVID19. Pembelajaran akan semakin bermakna jika guru dan siswa kerjasama untuk mendapatkan kualitas pendidikan yang lebih baik.

Berdasar dari masalah tersebut maka pembelajaran online yang menarik yang bervariasi akan memberikan manfaat bagi generasi emas dalam belajar. Yang tidak dilupakan juga guru harus memberikan pembelajaran yang kontekstual atau nyata agar mempunyai makna dan siswa menjadi generasi emas yang berkarakter.

\section{DAFTAR PUSTAKA}

Buckby, M. (1994). Games for Language Learning. Australia: Cambridge University Pres

Darman, R. A. (2017). Membangun Generasi Emas Indonesia Tahun 2045 Melalui Pendidikan Berkualitas Vol 3 no

https://mediaindonesia.com/read/detail/259270 -seluruh-pegiat-pendidikan-dimintabersiap-hadapi-era-society-5.0

Huda, M. (2013). Model-Model Pengajaran dan Pembelajaran. Yogyakarta: Pustaka Pelajar

Waryanto, N. H. (2006). Online learning sebagai Salah Satu Inovasi Pembelajaran. Jurnal Matematika Phytagoras Vol 2 No 1 hal 11-23

Wasisto, Agus. (2020) Publikasi Ilmiah Penelitian Tindakan Kelas. Yogyakarta: Penerbit Anom Pustaka

Wulandari, M. dan Almenda, T. (2020) Technology for English language Learning. Yogyakarta: Sanata Dharma University Press 